\title{
Retrieval of aerosol optical depth over land surfaces from AVHRR data
}

\author{
L. L. Mei ${ }^{1,2,6}$, Y. Xue ${ }^{1,3}$, A. A. Kokhanovsky ${ }^{2}$, W. von Hoyningen-Huene ${ }^{2}$, G. de Leeuw ${ }^{4,5}$, and J. P. Burrows ${ }^{2}$ \\ ${ }^{1}$ The Key Laboratory of Digital Earth Science, Institute of Remote Sensing and Digital Earth, Chinese Academy of Sciences, \\ Beijing 100094, China \\ ${ }^{2}$ Institute of Environmental Physics, University of Bremen, Otto-Hahn-Allee 1, 28359 Bremen, Germany \\ ${ }^{3}$ Faculty of Life Sciences and Computing, London Metropolitan University, 166-220 Holloway Road, London N7 8DB, UK \\ ${ }^{4}$ Department of Physics, University of Helsinki, Helsinki, Finland \\ ${ }^{5}$ Finnish Meteorological Institute, Climate Change Unit, Helsinki, Finland \\ ${ }^{6}$ University of the Chinese Academy of Sciences, Beijing 100039, China
}

Correspondence to: Y. Xue (xueyong@ radi.ac.cn)

Received: 29 November 2012 - Published in Atmos. Meas. Tech. Discuss.: 28 February 2013

Revised: 13 June 2014 - Accepted: 27 June 2014 - Published: 8 August 2014

\begin{abstract}
The Advanced Very High Resolution Radiometer (AVHRR) provides a global, long-term, consistent time series of radiance data in several wavebands which are used for the retrieval of surface spectral reflectance, albedo and surface temperature. Long-term time series of such data products are necessary for studies addressing climate change, sea ice distribution and movement, and ice sheet coastal configuration. AVHRR radiances have also been used to retrieve aerosol properties over ocean and land surfaces. However, the retrieval of aerosol over land is challenging because of the limited information content in the data which renders the inversion problem ill defined. Solving the radiative transfer equations requires additional information to reduce the number of unknowns. In this contribution we utilise an empirical linear relationship between the surface reflectances in the AVHRR channels at wavelengths of $3.75 \mu \mathrm{m}$ and $2.1 \mu \mathrm{m}$, which has been identified in the Moderate Resolution Imaging Spectroradiometer (MODIS) data. Following the MODIS dark target approach, this relationship is used to obtain the surface reflectance at $0.64 \mu \mathrm{m}$. The comparison of the estimated surface reflectances with MODIS reflectance products (MOD09) shows a strong correlation. Once this was established, the MODIS "dark-target" aerosol retrieval method was adapted to AVHRR data. A simplified look-up table (LUT) method, adopted from the Bremen AErosol Retrieval (BAER) algorithm, was used in the retrieval. The aerosol optical depth (AOD) values retrieved
\end{abstract}

from AVHRR with this method compare favourably with ground-based measurements, with $71.8 \%$ of the points located within $\pm(0.1+0.15 \tau)$ ( $\tau$ is the AOD) of the identity line. This method can be easily applied to other satellite instruments which do not have a $2.1 \mu \mathrm{m}$ channel, such as those currently planned to be used on geostationary satellites.

\section{Introduction}

Algorithms developed to retrieve aerosol properties from satellite-based passive instruments, such as radiometers, make optimum use of the information available in the radiation measured at the top of the atmosphere (TOA). The TOA radiation consists of backscattered and reflected upwelling radiation, ideally at different wavebands, multiple viewing angles and/or with polarisation information. The results further depend on the swath width, spatial and temporal resolution. An overview of aerosol retrieval algorithms and products is provided in Kokhanovsky and de Leeuw (2009), de Leeuw et al. (2011) and Mei et al. (2012). Aerosol retrieval is usually only done for cloud-free situations. If that has been verified, for example, by application of a cloud mask, the next important step in the retrieval of aerosol properties from TOA radiances (or reflectances) is the decoupling of the contributions from the surface and from atmospheric constituents. This can be achieved in several ways, 

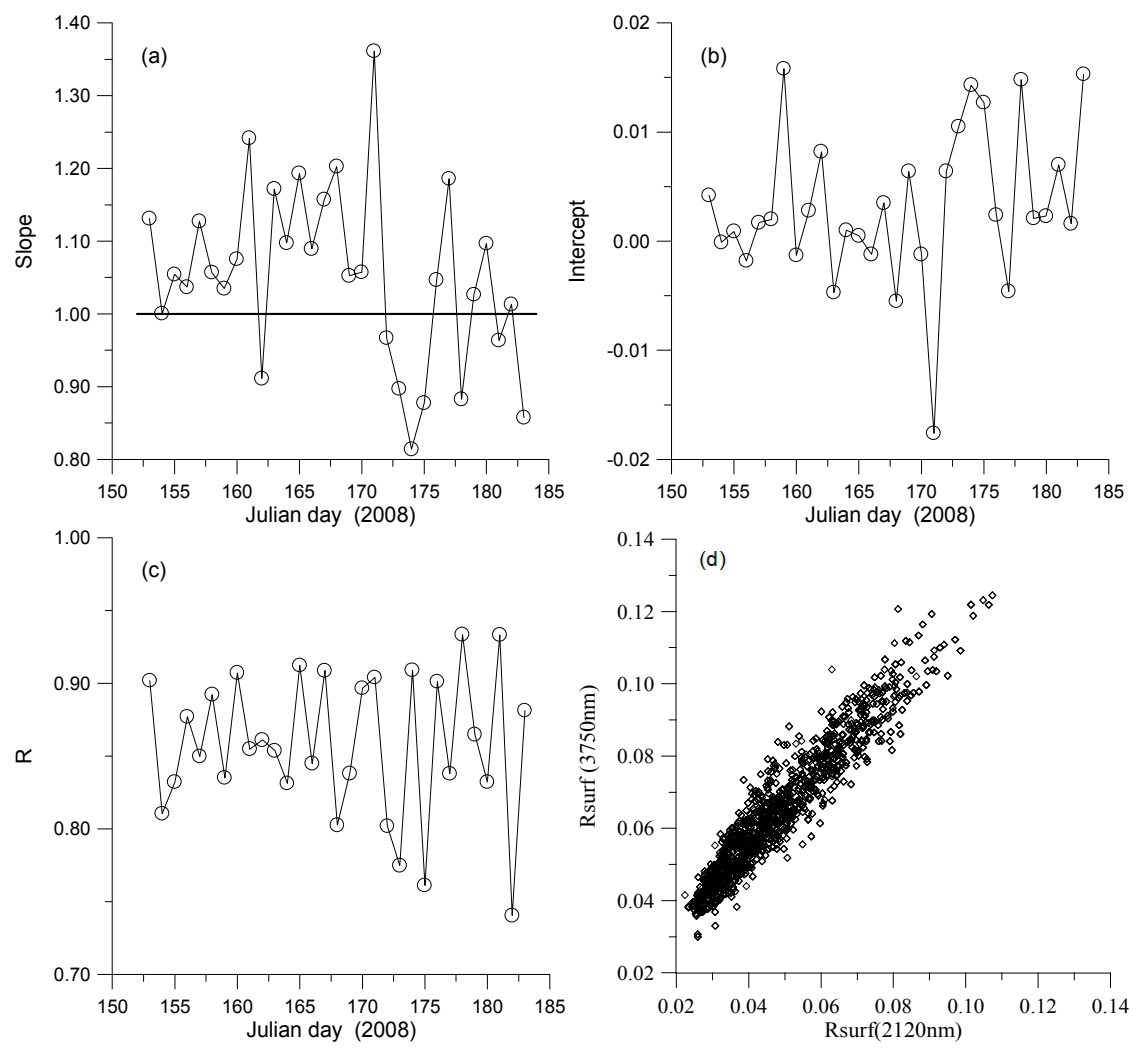

Figure 1. Statistic parameters between estimated MODIS $0.66 \mu \mathrm{m}$ surface reflectance and MODIS $0.66 \mu \mathrm{m}$ surface reflectance products for June 2008 over eastern China: (a) slope, (b) intercept, (c) correlation $(R)$, and (d) an example of the scattering plot of surface reflectance between $3.75 \mu \mathrm{m}$ and $2.12 \mu \mathrm{m}$.

depending on the instrument characteristics and in particular the number of viewing angles. For single-view instruments, such as MODIS, MERIS, SeaWiFS or AVHRR, assumptions need to be made on the surface reflectance. For instance, the "dark-target" approach developed for the retrieval of aerosol properties from MODIS data uses the $2.1 \mu \mathrm{m}$ band to estimate the reflectance for visible bands (Kaufman et al., 1997). The $2.1 \mu \mathrm{m}$ band is used because at this wavelength the effect of aerosol particles on the TOA reflectance is negligibly low (except for coarse mode particles such as for desert dust or sea spray aerosol). Then the relation is sought between the surface reflectances at $2.1 \mu \mathrm{m}$ and visible wavelengths. Similarly, Holzer-Popp et al. (2009) developed a regression function between the TOA reflectance at $1.6 \mu \mathrm{m}$ and the surface reflectance at $0.67 \mu \mathrm{m}$ and von Hoyningen-Huene et al. (2009) use the empirical relationship between $0.67 \mu \mathrm{m}$ and $2.1 \mu \mathrm{m}$ bands for sun glint correction for the multi-spectral imager (MSI) instrument. The Bremen AErosol Retrieval (BAER) algorithm for MERIS (von Hoyningen-Huene et al., 2003, 2011) utilises the the normalised difference vegetation index (NDVI). For bright surfaces, the deep blue approach has been developed for MODIS (Hsu et al., 2004) and SeaWiFS (Sayer et al., 2012; Hsu et al., 2013). In the most recent MODIS Collection 6 data set, the dark target and deep blue results have been combined. Some dual-view algorithms such as the AATSR dual-view (ADV) algorithm (Curier et al., 2009; Grey et al., 2006), the multiobservation approach for MODIS (Tang et al., 2005; Mei et al., 2013a), Advanced Along-Track Scanning Radiometer (AATSR) (Xue et al., 2009; Mei et al., 2013b) and the Jet Propulsion Laboratory (JPL) algorithm for the Multi-angle Imaging Spectroradiometer (MISR) (Diner et al., 2005) are based on the assumption that the surface reflectance can be approximated by a parameter which describes the variation with the wavelength and another one which describes the variation with the geometry (Flowerdew and Haigh, 1995). For geostationary satellites a time series method is employed assuming that the surface reflectance can be selected for each pixel during a certain period of time (Knapp et al., 2002, 2005) based on the assumption that the surface reflectance does not change significantly during that time period (Mei et al., 2012). In order to avoid cloud shadow effects, the second darkest image is preferred. The operational algorithm used to retrieve the AOD over ocean using Advanced Very High Resolution Radiometer (AVHRR) data (Ignatov et al., 2004) was used for MSG/SEVIRI AOD retrieval (Brindley et al., 2006). 


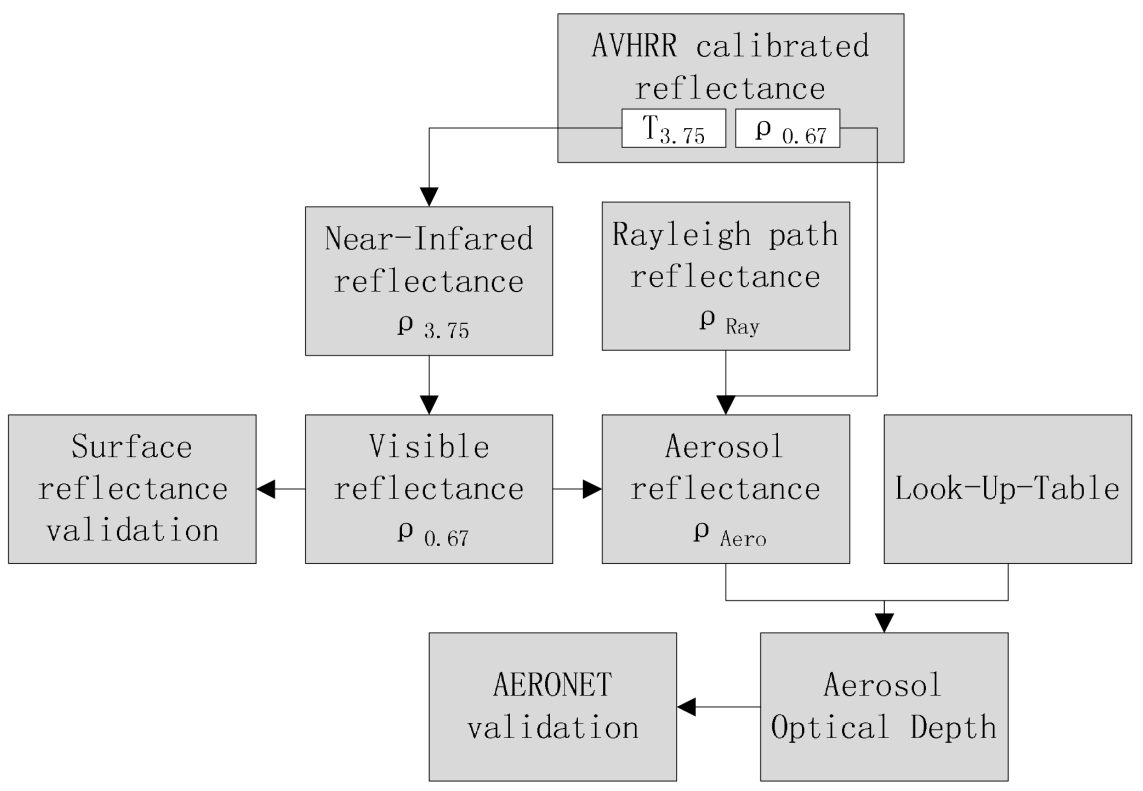

Figure 2. Scheme of the main steps of AVHRR retrieval procedure.

In this paper we describe an attempt to retrieve aerosol properties over land from AVHRR data. This is challenging because AVHRR has only two visible bands, which are quite broad, and no mid-infrared channel. Nevertheless, the use of AVHRR data to retrieve aerosol properties is attractive because AVHRR instruments have continuously been in polar orbits, on different satellites, since 1979 (Holben et al., 1992) and thus provide a unique data series for longterm analysis. Xue and Cracknel (1995) developed a retrieval approach using AVHRR data by solving a set of analytical equations. Takemata et al. (2006) derived the surface reflectance at $3.75 \mu \mathrm{m}$ using the Roger and Vermote (1998) scheme and then established an empirical relationship between the $0.64 \mu \mathrm{m}$ and $3.75 \mu \mathrm{m}$ bands using ground-based measurements. However, only 30 points were used for regression, which limited the algorithm to selected land-cover types or certain areas. Hauser et al. (2005) estimated the surface reflectance from a time series including a period of 44 days and then retrieved AOD using a radiative transfer code. Riffler et al. (2010) improved the method from Hauser et al. (2005) by considering a new surface estimating method as well as the aerosol type. Holben et al. (1992) tried to implement a retrieval algorithm previously developed for Landsat data to use with AVHRR data. In this paper we explore an approach in which we assume that the surface reflectance at $0.64 \mu \mathrm{m}$ can be obtained using an empirical relationship between the reflectances at that wavelength and at $3.75 \mu \mathrm{m}$, using the MODIS dark surface approach. After correction for surface effects on the top of atmosphere (TOA) reflectance, the AOD is retrieved using a look-up table (LUT) method adopted from the BAER algorithm (von Hoyningen-Huene et al., 2003, 2011).

\section{The retrieval algorithm}

The reflectance at the top of the atmosphere (TOA) is described by Eq. (1) (Chandrasekhar, 1950; Kaufman et al., 1997)

$R_{\mathrm{TOA}}\left(\lambda, \mu_{0}, \mu, \varphi\right)=$

$R_{\mathrm{atm}}\left(\lambda, \mu_{0}, \mu, \varphi\right)+\frac{A_{\mathrm{sfc}}(\lambda) \cdot T_{1}\left(\lambda, \mu_{0}\right) T_{2}(\lambda, \mu)}{1-A_{\mathrm{sfc}}(\lambda) \cdot s(\lambda)}$,

where $\theta=\arccos \mu$ is the satellite zenith angle; $\theta_{0}=$ $\arccos \mu_{0}$ is the solar zenith angle; $\varphi$ is the relative azimuth angle; $R_{\mathrm{TOA}}\left(\lambda, \mu_{0}, \mu, \varphi\right)$ is the TOA reflectance; $R_{\text {atm }}\left(\lambda, \mu_{0}, \mu, \varphi\right)$ is the atmospheric contribution to the TOA reflectance, which contains two parts, the aerosol reflectance $R_{\text {aero }}\left(\lambda, \mu_{0}, \mu, \varphi\right)$ and the Rayleigh reflectance $R_{\text {Ray }}\left(\lambda, \mu_{0}, \mu, \varphi\right)$ (von Hoyningen-Huene et al., 2003). $A_{\text {sfc }}(\lambda)$ is the surface spectral albedo, $T_{1}\left(\lambda, \mu_{0}\right)$ is total transmission of light propagating downward, $T_{2}(\lambda, \mu)$ is the total transmission of light propagating upward from the surface to the TOA and $s(\lambda)$ is the atmospheric hemispherical albedo. The basic definition of above parameters can be found here (http://6s.ltdri.org/). We can rewrite Eq. (1) as follows:

$R_{\mathrm{atm}}\left(\lambda, \mu_{0}, \mu, \varphi\right)=$

$R_{\mathrm{TOA}}\left(\lambda, \mu_{0}, \mu, \varphi\right)-\frac{A_{\mathrm{sfc}}(\lambda) \cdot T_{1}\left(\lambda, \mu_{0}\right) T_{2}(\lambda, \mu)}{1-A_{\mathrm{sfc}}(\lambda) \cdot s(\lambda)}$.

The aerosol reflectance was estimated using the Bremen AErosol Retrieval (BAER) (von Hoyningen-Huene et al., 2003) approach; see Eq. (3). The Raman-Pinty-Verstraete (RPV) bidirectional reflectance distribution function (BRDF) model (Maignan et al., 2004) was used to estimate $A_{\mathrm{sfc}}(\lambda)$. 


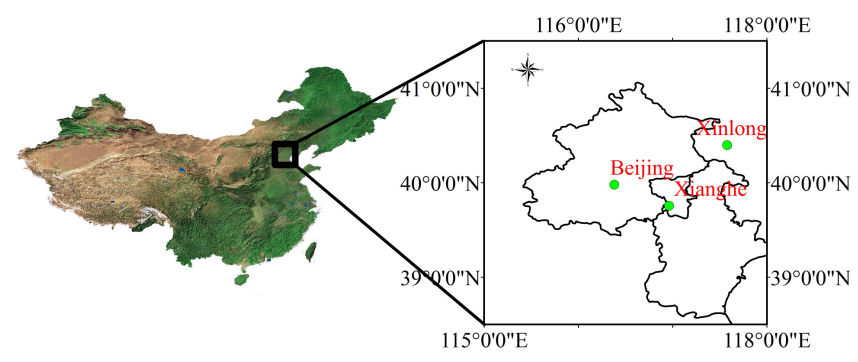

Figure 3. Study area in the NE of China. The location of AERONET sites in this area is indicated.

After removal of the Rayleigh reflectance, the relation between AOD and aerosol reflectance $\left(R_{\text {aero }}\left(\lambda, \mu_{0}, \mu, \varphi\right)\right)$ was used for AOD retrieval (von Hoyningen-Huene et al., 2011).

$$
\begin{aligned}
& R_{\text {aero }}\left(\lambda, \mu_{0}, \mu, \varphi\right)= \\
& \quad R_{\mathrm{TOA}}\left(\lambda, \mu_{0}, \mu, \varphi\right)-R_{\mathrm{Ray}}\left(\lambda, \mu_{0}, \mu, \varphi\right) \\
& \quad-\frac{A_{\mathrm{sfc}}(\lambda) \cdot T_{1}\left(\lambda, \mu_{0}\right) T_{2}(\lambda, \mu)}{1-A_{\mathrm{sfc}}(\lambda) \cdot s(\lambda)}
\end{aligned}
$$

The expressions for $T_{1}\left(\lambda, \mu_{0}\right), T_{2}\left(\lambda, \mu_{0}\right)$ and $s(\lambda)$ can be obtained using the approximate equations from Kokhanovsky et al. (2005). We also used the aerosol phase functions and single scattering albedo from the LACE-98 experiment (von Hoyningen-Huene et al., 2011), which were applied in radiative transfer calculations to build look-up tables (LUT). LUT were used for faster processing by avoiding time-consuming radiative transfer computations during each retrieval. In order to estimate the right item in Eq. (3), Rayleigh path reflectance $\left(R_{\text {Ray }}\right)$ and surface reflectance at $0.64 \mu \mathrm{m}\left(R_{\text {Surf }}(0.64 \mu \mathrm{m})\right)$, which is used to calculate surface albedo $\left(A_{\mathrm{sfc}}(\lambda)\right)$ are needed. The Rayleigh path reflectance $\left(R_{\text {Ray }}\right)$ is determined by the Rayleigh optical depth, $\tau_{\text {Ray }}$, (Frohlich and Shaw, 1980) and the Rayleigh phase function, $P_{\text {Ray }}(\Phi)$, is given by Eq. (4):

$R_{\text {Ray }}=\frac{\tau_{\text {Ray }} \times P_{\text {Ray }}(\Phi)}{4 \mu \mu_{0}}$,

where

$\tau_{\text {Ray }}=0.00864 \lambda^{-\left(3.96+0.074 \lambda+\frac{0.05}{\lambda}\right)}$,

and $\lambda$ is the wavelength;

$P_{\text {Ray }}(\Phi)=\frac{3}{4}\left(1+\cos ^{2} \Phi\right)$, where $\Phi$ is the scattering angle.

To obtain the surface reflectance in the AVHRR visible channel $(0.64 \mu \mathrm{m})$, we follow the method used in the MODIS dark surface approach. However, because AVHRR does not have a $2.1 \mu \mathrm{m}$ band, we explore the use of the $3.75 \mu \mathrm{m}$ channel instead. To do this, the relationship between reflectances at $2.1 \mu \mathrm{m}$ and $3.75 \mu \mathrm{m}$ using MODIS data needs to be established (see Fig. 1d). We assume that the aerosol scattering effect can be neglected at both $2.1 \mu \mathrm{m}$ (Kaufman et al., 1997) and $3.75 \mu \mathrm{m}$ (Holben et al., 1992). We do not determine the relationship between surface reflectance at $0.64 \mu \mathrm{m}$ and $3.75 \mu \mathrm{m}$ directly, because of the uncertainty associated with the $0.64 \mu \mathrm{m}$ channel surface reflection and required atmospheric correction which depends on AOD which in turn is the parameter we aim to retrieve from AVHRR data. Instead we try to use additional MODIS reflectance products for the evaluation of the statistic relationship, that is, we use the relationship between $2.1 \mu \mathrm{m}$ and $3.75 \mu \mathrm{m}$ and the relationship between $2.1 \mu \mathrm{m}$ and $0.64 \mu \mathrm{m}$, all of these obtained from MODIS, separately.

The reflectance at $3.75 \mu \mathrm{m}$ is given by Eq. (7) (Roger and Vermote, 1998; Allen et al., 1990):

$R(3.75 \mu \mathrm{m})=\frac{\pi\left[B\left(T_{3.75}^{\mathrm{m}}\right)-B\left(T_{3.75}^{\mathrm{e}}\right)\right]}{L_{0} \mu_{0} t_{1} t_{2}-\pi B\left(T_{3.75}^{\mathrm{e}}\right) t_{2}}$,

where $R(3.75 \mu \mathrm{m})$ is the surface reflectance at $3.75 \mu \mathrm{m}$, $B\left(T_{3.75}^{\mathrm{m}}\right)$ is the Planck function for the temperature $T_{3.75}^{\mathrm{m}}$, $T_{3.75}^{\mathrm{m}}$ is the satellite measurement brightness temperature at $3.75 \mu \mathrm{m}, T_{3.75}^{\mathrm{e}}$ is the brightness temperature at $3.75 \mu \mathrm{m}$ estimated from brightness temperatures and emissivity's in channels 4 and 5 (Roger and Vermote, 1998), $L_{0}$ is the solar constant and $\mu_{0}$ is cosine of solar zenith angle. $t_{1}$ is the total transmission of light propagating downward in channel 3 , which contains the effect of water vapor and other gases (Roger and Vermote, 1998); $t_{2}$ is the total transmission of light propagating upward in channel 3.

Based on the statistical relationship between $R_{\text {Surf }}$ (3.75 $\mu \mathrm{m})$ and $R_{\text {Surf }}(2.12 \mu \mathrm{m})$ and the empirical relationship between $R_{\text {Surf }}(0.64 \mu \mathrm{m})$ and $R_{\text {Surf }}(2.12 \mu \mathrm{m})$ used in the MODIS dark-target algorithm $R_{\text {Surf }}(0.64 \mu \mathrm{m})=0.5 \times R_{\text {Surf }}$ $(2.12 \mu \mathrm{m})$, we obtain

$R_{\text {Surf }}(0.64 \mu \mathrm{m})=2.5 \times a \times R_{\text {Surf }}(3.75 \mu \mathrm{m})+2.5 \times b+c$,

where $a$ and $b$ are functions of the normalised difference vegetation index (NDVI) and $c$ is a correction part for scattering angle, which is similar to that proposed by Holzer-Popp et al. (2009).

$$
\begin{aligned}
& a=-0.85 \times(\mathrm{NDVI})+0.85, b=-0.05 \times \mathrm{NDVI}+0.05, \\
& c=0.1(\cos \Phi-\cos 150) .
\end{aligned}
$$

The NDVI is determined for AVHRR as

$$
\mathrm{NDVI}=\frac{R_{0}(0.64 \mu \mathrm{m})-R_{0}(0.87 \mu \mathrm{m})}{R_{0}(0.64 \mu \mathrm{m})+R_{0}(0.87 \mu \mathrm{m})},
$$

where $R_{0}(0.64 \mu \mathrm{m})$ is the reflectance at the TOA at $0.64 \mu \mathrm{m}$ and $R_{0}(0.87 \mu \mathrm{m})$ is the reflectance at the TOA at $0.87 \mu \mathrm{m}$ and the NDVI values need to be corrected for AOD effects as proposed by Holzer-Popp et al. (2009). 

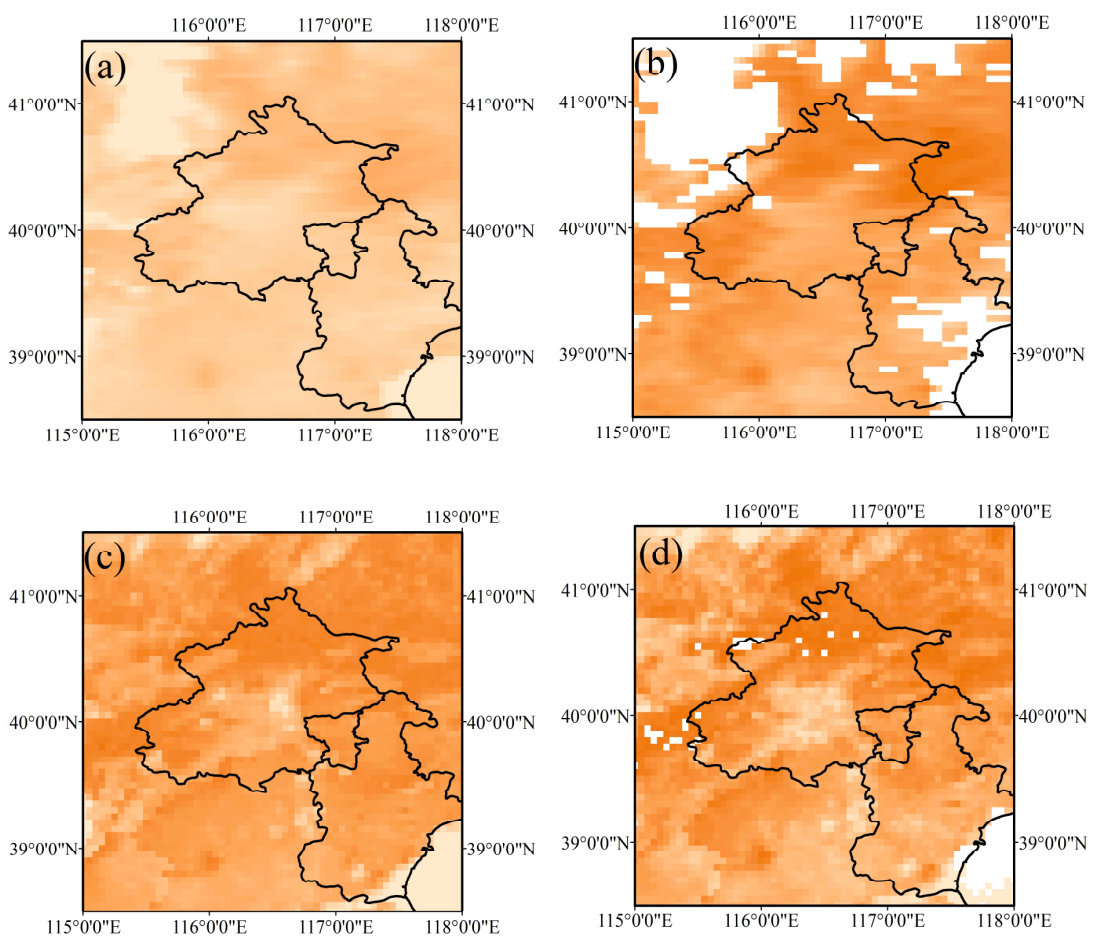

Figure 4. An example of TOA and surface reflectances for AVHRR and MODIS (the most bright surface is due to cloud mask or negative estimated value). (a) AVHRR TOA reflectance $(0.64 \mu \mathrm{m})$; (b) estimated AVHRR surface reflectance $(0.64 \mu \mathrm{m})$; (c) MODIS daily surface reflectance product (MOD09) $(0.66 \mu \mathrm{m})$; and (d) estimated MODIS surface reflectance $(0.66 \mu \mathrm{m})$.

The MODIS surface product (MOD09) was used for the evaluation of Eq. (8). Figure 1 demonstrates an example of the statistical parameters (slop, intercept and correlation) between the estimated MODIS $0.66 \mu \mathrm{m}$ surface reflectance from Eq. (8) and the MODIS $0.66 \mu \mathrm{m}$ surface reflectance product. Figure 1 shows that the estimated surface reflectance correlates well with the MODIS product, with an average uncertainty of $\pm 20 \%$.

The flowchart for the AVHRR retrieval procedure is shown in Fig. 2. The Earth surface reflectance at $3.75 \mu \mathrm{m}$ is determined using Eq. (7) (Roger and Vermote, 1998) while the Rayleigh path reflectance is calculated using Eq. (4). Using the statistical regression Eq. (8), the surface reflectance at $0.66 \mu \mathrm{m}$ can be obtained. Then the aerosol reflectance can be calculated based on Eq. (3), which in turn is used to determine the AOD using a simplified LUT method, adopted from the BAER algorithm (von Hoyningen-Huene et al., 2011). In the BAER algorithm, the discrete output from a radiative transfer model (Rozanov et al., 2014) is used to derive parameterisations formulated as polynomials of second degree (von Hoyningen-Huene et al., 2003, 2011).

\section{Study area and data set}

Beijing is the capital of China located near the northwest border of the Great North China Plain (See Fig. 3). The region is experiencing serious environmental problems, caused by fast economic development and the resultant release of pollutants from anthropogenic activities such as changes in agricultural and industrial activities, urbanisation and increased traffic, etc. In addition to dust transported from Mongolia which is dominant during the spring and summer, anthropogenic emissions are the main contributors to pollution over Beijing. The pollution levels may become very high due to the location of Beijing at the northern edge of the North China Plain, which is bounded in the north and west by mountain ranges. Winds from the north or west push pollutants out of the city, while those from the south and east result in accumulation of pollutants over the city along the mountain front (http://earthobservatory.nasa.gov/IOTD/view.php? $\mathrm{id}=38290$ ). Many previous researches show that the AOD over Beijing is often around 0.4-0.5 and sometimes even larger than 2.0 (Sundström et al., 2012). The annual average concentration of $\mathrm{PM}_{2.5}$ was about $101 \mu \mathrm{g} \mathrm{m} \mathrm{m}^{-3}$ in 2001 (He et al., 2001) and about $149 \mu^{-3} \mathrm{~m}^{-3}$ in 2004 (Guinot et al., 2007).

As a result of the relatively large AVHRR swath of approximately $2400 \mathrm{~km}$, the NOAA platforms view the same Earth location twice a day (ascending and descending) and the daytime observation is used for aerosol retrieval. In this work, two channels $(0.64 \mu \mathrm{m}$ and $3.75 \mu \mathrm{m})$ of the AVHRR instrument (ascending) on board the polar orbiting 

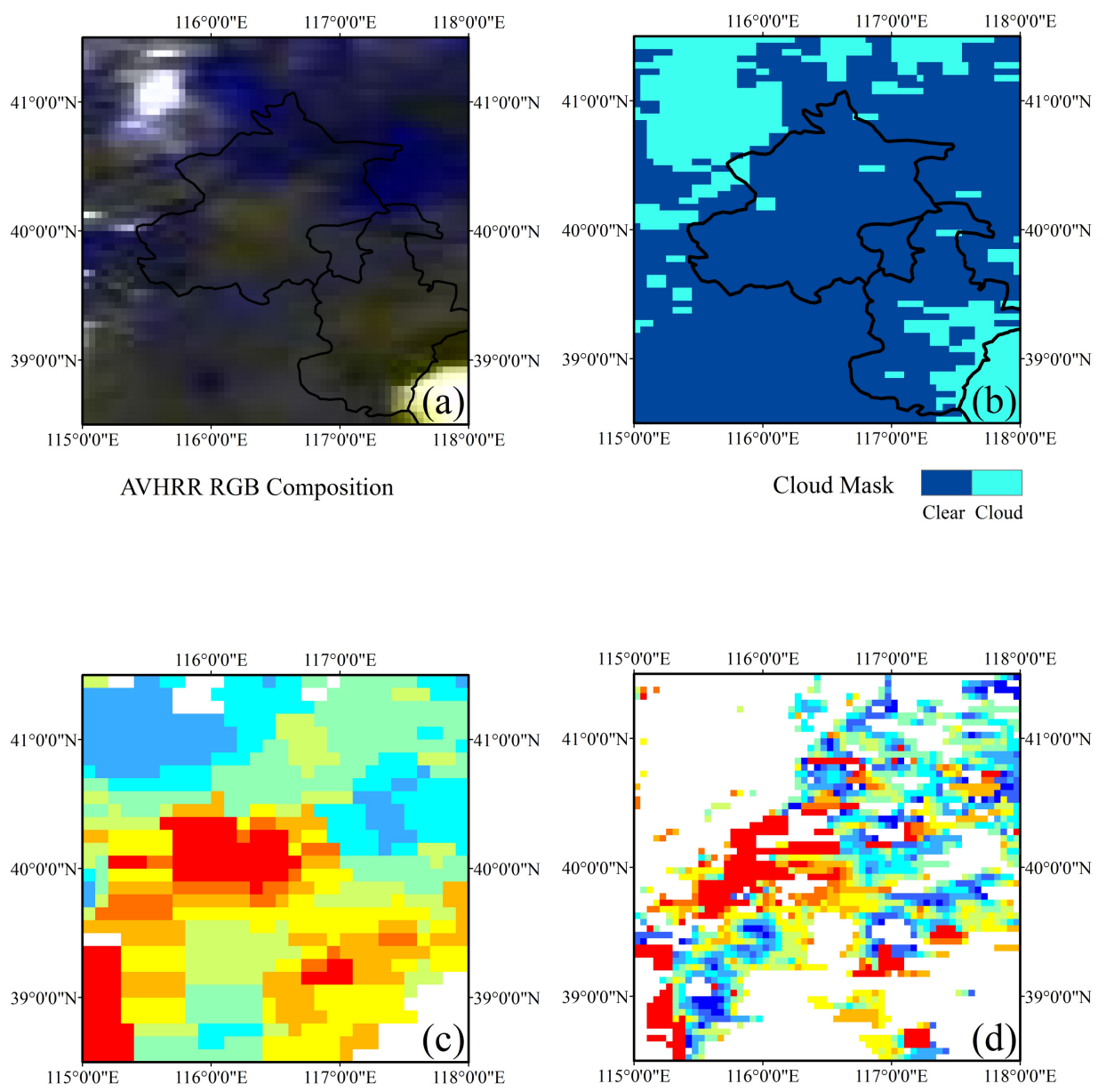

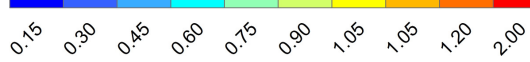

Figure 5. An example of MODIS 0.55 $\mu$ m AOD product (Collection 5) (c) and AVHRR-derived 0.64 $\mu \mathrm{m}$ AOD (d) and the corresponding RGB composition map (a) and AVHRR cloud mask product (b).

NOAA-18 (June and July 2006-2010) and NOAA-19 (June and July 2011) satellites are used. MODIS level 2 aerosol products (MOD04) and MODIS surface reflectance products (MOD09) were used for the comparison of retrieved AOD and surface reflectance derived from AVHRR. For evaluation of the retrieved AODs, sun photometer data from the AERONET (Holben et al., 1998) were used.

\section{Results and validation}

As an example, the TOA reflectance measured by AVHRR at $0.64 \mu \mathrm{m}$ is presented in Fig. 4 together with the surface reflectance derived from that data using Eq. (8), the MODIS surface reflectance product at $0.66 \mu \mathrm{m}$ (MOD09) and the MODIS surface reflectance at $0.66 \mu \mathrm{m}$ estimated using Eq. (8), all for 9 June 2008. Comparison of the images in Fig. 4 shows that the estimated AVHRR reflectance is similar to the MOD09 daily reflectance product. Further analysis shows that $87 \%$ MODIS reflectances in this image are in the range of [0.06-0.1], as compared to $83 \%$ of the AVHRR reflectances. Note that the MOD09 product was resized to the same spatial resolution as AVHRR.

An example of the AOD at $0.64 \mu \mathrm{m}$ retrieved from AVHRR data over China, using the method presented above is shown in Fig. 5, together with the AVHRR RGB composition map and the cloud map for the same scene, and the MODIS Collection 5 AOD at $0.55 \mu \mathrm{m}$. The AVHRR and MODIS AOD show a similar spatial distribution. In this qualitative comparison on the spatial distribution of AOD over the study region, the small difference in wavelength of the two instruments is ignored. The highest AOD values occur in the high population density areas with universities and technology parks. Figure 5 also shows the high AOD to the southwest of Beijing, which may contribute to the pollution in that city due to transport as confirmed by information on wind 
directions data from http://envf.ust.hk/dataview/gts/current/ query_gts_series.py?src_type=ax, which shows that the governing wind direction during the study period was indeed from the southwest. Humidity may be another contributing factor since particle size is sensitive to changes in relative humidity. For instance, the humidity in the southern part was about $60 \%$ while it was about $40 \%$ in the northern part. Much farmland is located in the southwestern part of Beijing, where during summer, the harvest time for crops such as wheat, and biomass burning causes high AODs.

In some areas the AVHRR-derived AOD is low in comparison with MODIS and confirmed by comparison with AERONET. Ignatov (2002) investigated the calibration uncertainty of NOAA_14 AVHRR and estimated an uncertainty in the calibration of $\pm 5-10 \%$. The calibration is better for NOAA-18 (launched in 2005) and NOAA-19 (launched in 2009), which are used in the paper, but calibration issues still exist (Meirink et al., 2013). An uncertainty in the calibration causes deviation in the TOA reflectance which may result in an increase/decrease of the retrieved surface reflectance, depending on the method of estimation surface reflectance (Hauser et al., 2005), and thus cause an uncertainty in the retrieved AOD. Apart from the calibration problem, there are two other possibilities which may cause underestimation of the AVHRR-retrieved AOD. One could be overestimation of the surface reflectance and the other could be the use of inappropriate aerosol optical properties in the LUTs. Figure 4 shows that the estimated surface reflectance agrees qualitatively quite well with the MOD09 daily surface reflectance product. Hence it is likely that the underestimation is caused by the use of inappropriate aerosol properties in the LUT, especially for high AOD. The absorption is not treated very well in the BAER LUT. Comparison with AERONET data shows that for all match-ups in the Beijing area, the AODs from AVHRR were underestimated. This is similar to earlier findings using the BAER LUT (von Hoyningen-Huene et al., 2011).

The AOD values at $0.64 \mu \mathrm{m}$ retrieved with our algorithm were evaluated by comparison with collocated sun photometer data provided by the AERONET sites in Beijing, Xianghe and Xinlong from June and July 2006-2011 as well as from another eighteen sites (Bac_Lieu, EPANCU, Gosan_SNU, Gwangju_K-JIST, Issyk-Kul, Kanpur, Karachi, MCO-Hanimaadhoo, NCU_Taiwan, Noto, Lulin, Mukdahan, SACOL, Shouxian, Singapore, Taipei_CWB, Ussuriysk, and Yakutsk) during June and July 2008; results are shown in Fig. 6. The overpass time for each site was queried on the AVHRR home page. We follow the validation method presented by Ichoku et al. (2001). Averaged AOD values are used corresponding to an overpass time of $\pm 30 \mathrm{~min}$ from the AERONET observation. AOD values derived from AVHRR data were averaged to an area of $50 \mathrm{~km} \times 50 \mathrm{~km}$ around the AERONET sites, with the exclusion of pixels where the AVHRR-derived AOD had a standard deviation larger than 0.18 in the $50 \mathrm{~km} \times 50 \mathrm{~km}$

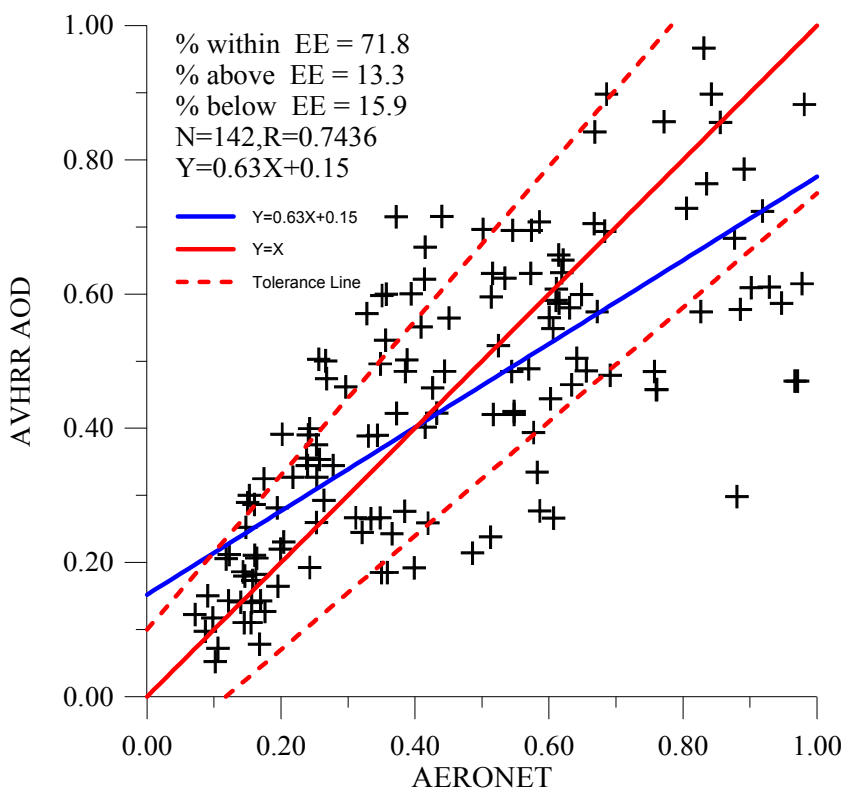

Figure 6. Scatter plot of AVHRR-derived AOD $(0.64 \mu \mathrm{m})$ versus AERONET AOD for $0.64 \mu \mathrm{m}$. Text at the top describes the number of collocation $(N)$, the regression curve, correlation $(R)$, and the tolerance line of $\pm(0.1+15 \%)$.

window. Such high standard deviations may be caused by apparently enhanced AOD due to undetected clouds. Hence such pixels are excluded to avoid cloud-contaminated pixels. On the other hand, we reduce the number of LUT in terms of the polynomial by the consideration of single scattering approximation to correct for the different solar and viewing geometries and this approximation is valid for low AOD, but deviates for larger AOD. The deviations start at AOD larger than 1.0 and increase with increasing wavelength.

The comparison in Fig. 6 shows 142 match-ups, $71.8 \%$ of which are located within $\pm(0.1+15 \%)$ of the identity line and the correlation coefficient is 0.74 . However there is no perfect match with an intercept of around 0.15 and a slope of 0.63 . The underestimation is due to the occurrence of absorbing aerosol in the study area which is not included in the BAER LUTs used in the retrieval. Figure 6 also shows that the retrieved AOD is sometimes overestimated, which is due to underestimation of surface reflectance. Cloud contamination may also be a factor here and pixels contaminated with residual clouds may not be completely removed by selection of pixels with a standard deviation of less than 0.18 .

The statistical coefficient derived from MODIS data for the relation between the surface reflectances at 0.64 and $2.1 \mu \mathrm{m}$ is used as prior knowledge in our retrieval method. However, we need to find the empirical relationships for different surface types and in different seasons. Figure 7, as an example, shows the AOD distribution over China derived from AVHRR and MODIS data. Here MODIS AOD at $0.64 \mu \mathrm{m}$ was converted from AOD at $0.55 \mu \mathrm{m}$ using the 

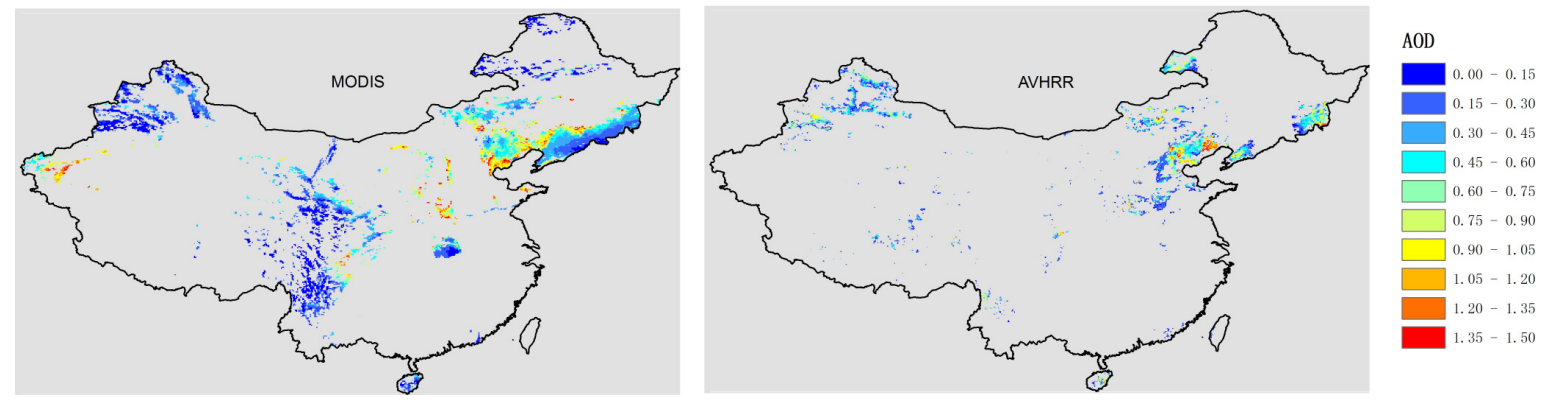

Figure 7. Aerosol optical depth distribution of $0.64 \mu \mathrm{m}$ from AVHRR and MODIS/TERRA over China on 9 June 2008. Here MODIS AOD at $0.64 \mu \mathrm{m}$ was converted from AOD at $0.55 \mu \mathrm{m}$ using a MODIS Ångström coefficient product.

MODIS Ångström coefficient product. We can see that the AHVRR and MODIS AOD distributions agree quite well over central and eastern China; however, over western China, AVHRR overestimates the AOD. This is mainly due to the surface properties: the surface over western China is very bright and the dark surface assumption does not apply. Equation (8) may also be invalid for this bright region. As a result, the surface reflectance is underestimated which in turn causes overestimation of the AOD.

\section{Conclusions}

An aerosol retrieval algorithm has been presented which uses the single visible band of AVHRR, with support from the infrared channel to determine the surface reflectance. The main problem in aerosol retrieval from AVHRR data is that only one visible wavelength is available. Besides, there are two main limitations for the algorithm presented in this paper. The first one is the effect from the emissivity, which may affect the surface reflectance at $3.75 \mu \mathrm{m}$. This effect will not be a great issue for a small study area as used in the study presented here because for such a small area the surface properties are expected be relatively constant (Jin and Liang, 2006). However, for larger areas we need the support of an emissivity data set. The other problem is that a simple LUT was used which has been derived based on a phase function measured during the Lace experiment in 1998 (Von Hoyningen-Huene et al., 2003, 2011) and this phase function may not be representative for the situation over the Beijing area, especially with regards to aerosol absorption. The developed algorithm is the first step towards the use of AVHRR data for the retrieval of AOD over land.

Acknowledgements. This work was partly supported by the National Natural Science Foundation of China (NSFC) under grant no. 41271371, the Major International Cooperation and Exchange Project of NSFC (grant no. 41120114001), and the Ministry of Science and Technology (MOST) of China under grant no. 2013CB733403. The authors also thanks for the help of dealing with MOD09 data from Fei Li from Institute of Remote
Sensing and Digital Earth, Chinese Academy of Sciences. Thanks for Chi Li from Institute of Remote Sensing and Digital Earth of the Chinese Academy of Sciences for pre-processing two months data set. The author appreciates the valuable comments from Dr. Jie Guang from Institute of Remote Sensing and Digital Earth, Chinese Academy of Sciences. L. L. Mei would like to thank the Director Prize from the Institute of Remote Sensing and Digital Earth of Chinese Academy of Sciences. The contribution from G. de Leeuw was supported by ESA through the Aerosol-cci: ESA-ESRIN project AO/1-6207/09/I-LG, Globemission: ESAESRIN Data Users Element (DUE), project AO/1-6721/11/I-NB and by the European Commission through projects Marco Polo: EU FP7 SPACE grant agreement no. 606953, MEGAPOLI: EU FP7 FP7-ENV-2007.1.1.2.1 and EUCAARI: EU FP6, contract no. 036833-2, and by the Centre on Excellence in Atmospheric Science funded by the Finnish Academy of Sciences Excellence (project no. 272041). AVHRR data were available through NOAA (http://www.nsof.class.noaa.gov/saa/products/welcome), MODIS data were available through NASA (http://modis.gsfc.nasa.gov/) and meteorological data came from (http://envf.ust.hk/dataview/ gts/current/query_gts_series.py?src_type=ax). Many thanks are due to the PI investigators with the AERONET sites used in this paper. Alexander Kokhanovsky acknowledges the support of the DFG Projects Terra and RESINC-II. The authors also wish to thank the Michael J. Garay and the anonymous reviewer for their constructive comments.

Edited by: J. Cermak

\section{References}

Allen, R. C., Durkee, P. A., and Wash, C. H.: Snow/cloud discrimination with multispectral satellite measurements, J. Appl. Meteorol., 29, 994-1004, 1990.

Brindley, H. E. and Ignatov, A.: Retrieval of mineral aerosol optical depth and size information from eteosat Second Generation SEVIRI solar reflectance bands, Remote Sens. Environ., 102, 344363, 2006.

Chandrasekhar, S.: Radiative Trasfer, London (Oxford University Press), 1950.

Curier, L., de Leeuw, G., Kolmonen, P., Sundstrom, A.-M., Sogacheva, L., and Bennouna, Y.: Aerosol retrieval over land using the (A)ATSR dual-view algorithm, in: Satellite Aerosol Remote 
Sensing over Land, edited by: Kokhanovsky, A. A. and de Leeuw, G., Chichester, UK, Praxis Publishing, 135-160, 2009.

de Leeuw, G., Kinne, S., Leon, J. F., Pelon, J., Rosenfeld, D., Schaap, M., Veefkind, P.J., Veihelmann, B., Winker, D. M., and von Hoyningen-Huene, W.: Retrieval of aerosol properties, in: The Remote Sensing of Tropospheric Composition from Space, edited by: Burrows, J. P., Platt, U., and Borrell, P., 536 pp., Springer-Verlag Berlin Heidelberg, ISBN: 978-3-642-14790-6, 359-313, doi:10.1007/978-3-642-14791-3, 2011.

Diner, D. J., Martonchik, J. V., Kahn, R. A., Pinty, B., Gobron, N., Nelson, D. L., and Holben, B. N.: Using angular and spectral shape similarity constraints to improve MISR aerosol and surface retrievals over land, Remote Sens. Environ., 94, 155-171, 2005.

Flowerdew, R. J. and Haigh, J. D.: An approximation to improve accuracy in the derivation of surface reflectances from multi-look satellite radiometers, Geophys. Res. Lett., 22, 1693-1696, 1995.

Frohlich, C., and Shaw, G. E.: New determination of Rayleigh scattering in the terrestrial atmosphere, Appl. Optics, 19, 1773-1775, 1980.

Grey, W. M. F., North, P. R. J., Los, S. O., and Mitchell, R. M.: Aerosol optical depth and land surface reflectance from multiangle AATSR measurements: global validation and inter-sensor comparisons, IEEE Trans. Geosci. Remote Sens., 44, 2184 2197, 2006.

Guinot, B., Cachier, H., Sciare, J., Yu, T., Wang, X., and Yu, J. H.: Beijing aerosol: Atmospheric interactions and new trends, J. Geophys. Res., 112, D14314, doi:10.1029/2006JD008195, 2007.

Hauser, A., Oesch, D., Foppa, N., and Wunderle, S.: NOAA AVHRR derived aerosol optical depth over land, J. Geophys. Res., 110, D08204, doi:10.1029/2004JD005439, 2005.

He, K., Yang, F. M., Ma, Y. L., Zhang, Q., Yao, X. H., Chan, C. K., Cadle, S., Chan, T., and Mulawa, P.: The characteristics of $\mathrm{PM}_{2.5}$ in Beijing, China, Atmospheric Environment, 35, 49594970, 2001.

Holben, B. N., Vermote, E., Kaufman, Y. J., Tanre, D., and Kalb, V.: Aerosol retrieval over Land fromn AVHRR data-Application for Atmospheric Correction, IEEE Trans. Geosci. Remote Sens., 30, 212-222, 1992

Holben, B. N., Eck, T. F., Slutsker, I., Tanre, D., Buis, J. P., Setzer, A., Vermote, E., Reagan, J. A., Kaufman, Y. J., Nakajima, T., Lavenu, F., Jankowiak, I., and Smirnov, A.: AERONET - A Federated Instrument Network and Data Archive for Aerosol Characterization, Remote Sens. Environ., 66, 1-16, 1998.

Holzer-Popp, T., Schroedter-Homscheidt, M., Breitkreuz, H., Martynenko, D. and Kluser, L.: Benefits and limitations of the synergistic aerosol retrieval SYNAER, in: Satellite Aerosol Remote Sensing over Land, edited by: Kokhanovsky, A. A. and de Leeuw Chichester, G., UK, Praxis Publishing, 227-264, 2009.

Hsu, N. C., Tsay, S. C., King, M. D., and Herman, J. R.: Aerosol properties over bright-reflecting source regions, IEEE Trans. Geosci.Remote Sens., 42, 557-569, 2004.

Hsu, N. C., Jeong, M.-J., Bettenhausen, C., Sayer, A. M., Hansell, R., Seftor, C. S., Huang, J., and Tsay, S.-C.: Enhanced Deep Blue aerosol retrieval algorithm: The second generation, J. Geophys. Res. Atmos., 118, 9296-9315, doi:10.1002/jgrd.50712, 2013.

Ichoku, C., Chu, D. A., Mattoo, S., Kaufman, Y. J., Remer, L. A., Tanre, D., Slutsker, I., and Holben, B. N.: Techniques of global validation of aerosol retrievals from MODIS, in: Proceedings of the IEEE Geoscience and Remote Sensing Symposium held in
Sydney, Australia, 9-13 July 2001, 3, 1203-1205, Piscataway, NJ, IEEE, doi:10.1109/IGARSS.2001.976792, 2001.

Ignatov, A.: Sensitivity and information content of aerosol retrievals from Advanced Very High Resolution Radiometer: Radiometric factors, Appl. Optics, 41, 991-1011, 2002.

Ignatov, A., Sapper, J., Cox, S., Laszlo, I., Nalli, N. R., and Kidwell, K. B.: Operational Aerosol Observations (AEROBS) from AVHRR/3 On Board NOAA-KLM Satellites, J. Atmos. Oceanic Technol., 21, 3-26, doi:10.1175/15200426(2004)021<0003:OAOAFO>2.0.CO;2, 2004.

Jin, M. L. and Liang, S. L.: An Improved Land Surface Emissivity Parameter for Land Surface Models Using Global Remote Sensing Observations, J. Climate, 19, 2867-2881, doi:10.1175/JCLI3720.1, 2006.

Kaufman, Y. J., Tanre, D., Remer, L. A., Vermote, E. F., Chu, A., and Holben, B. N.: Operational remote sensing of tropospheric aerosol over land from EOS moderate resolution imaging spectroradiometer, J. Geophys. Res, 102, 17051-17067, doi:10.1029/96JD03988, 1997.

Knapp, K. R., Vonder Haar, T. H., and Kaufman, Y. J.: Aerosol optical depth retrieval from GOES-8: Uncertainty study and retrieval validation over South America, J. Geophys. Res., 107, 4055, doi:10.1029/2001JD000505, 2002.

Knapp, K. P., Frouin, R., Kondragunta, S., and Prados, A.: Toward aerosol optical depth retrieval over land from GOES visible radiances: determining surface reflectance, Int. J. Remote Sens., 26, 4097-4116, 2005.

Kokhanovsky, A. A. and de Leeuw, G. (Eds.): Satellite Aerosol Remote Sensing Over Land, Springer-Praxis (Berlin), ISBN 978-3540-69396-3, 388 pp., 2009.

Kokhanovsky, A. A., Mayer, B., and Rozanov, V. V.: A parameterization of the diffuse transmittance and reflectance for aerosol remote sensing problems, Atmos. Res., 73, 37-43, 2005.

Maignan, F., Breòn, F.-M., and Lacaze, R.: Bidirectional reflectance of Earth targets: valuation of analytical models using a large set of spaceborne measurements with emphasis on the Hop Spot, Remote Sens. Environ., 90, 210-220, 2004.

Mei, L. L., Xue, Y., de Leeuw, G., Holzer-Popp, T., Guang, J., Li, Y., Yang, L., Xu, H., Xu, X., Li, C., Wang, Y., Wu, C., Hou, T., He, X., Liu, J., Dong, J., and Chen, Z.: Retrieval of aerosol optical depth over land based on a time series technique using MSG/SEVIRI data, Atmos. Chem. Phys., 12, 9167-9185, doi:10.5194/acp-12-9167-2012, 2012.

Mei, L. L., Xue, Y., de Leeuw, G., von Hoyningen-Huene, W., Kokhanovsky, A. A., Istomina, L., Guang, J., and Burrows, J. P.: Aerosol optical depth retrieval in the Arctic region using MODIS data over snow, Remote Sens. Environ., 128, 234-245, doi:10.1016/j.rse.2012.10.009, 2013a.

Mei, L. L., Xue, Y., Kokhanovsky, A. A., von Hoyningen-Huene, W., Istomina, L., de Leeuw, G., Burrows, J. P., and Guang, J.: Aerosol optical depth retrieval over snow using AATSR data, Int. J. Remote Sens., 34, 5030-5041, 2013 b.

Meirink, J. F., Roebeling, R. A., and Stammes, P.: Inter-calibration of polar imager solar channels using SEVIRI, Atmos. Meas. Tech., 6, 2495-2508, doi:10.5194/amt-6-2495-2013, 2013.

Riffler, M., Popp, C., Hauser, A., Fontana, F., and Wunderle, S.: Validation of a modified AVHRR aerosol optical depth retrieval algorithm over Central Europe, Atmos. Meas. Tech., 3, 12551270, doi:10.5194/amt-3-1255-2010, 2010. 
Roger, J. C. and Vermote, E. F.: A method to retrieval the reflectivity signature at $3.75 \mu \mathrm{m}$ from AVHRR data, Remote Sens. Environ., 64, 103-114, 1998.

Rozanov, V. V., Rozanov, A. V., Kokhanovsky, A. A., and Burrows, J. P.: Radiative transfer through terrestrial atmosphere and ocean: Software package SCIATRAN, J. Quant. Spectr. Radiative Transfer, 133, 13-71, 2014.

Sayer, A. M., Hsu, N. C., Bettenhausen, C., Jeong, M.-J., Holben, B. N., and Zhang, J.: Global and regional evaluation of overland spectral aerosol optical depth retrievals from SeaWiFS, Atmos. Meas. Tech., 5, 1761-1778, doi:10.5194/amt-5-1761-2012, 2012.

Sundström, A.-M., Kolmonen, P., Sogacheva, L., and de Leeuw, G.: Aerosol retrievals over China with the AATSR Dual-View Algorithm, Remote Sens. Environ., 116, 189-198, 2012.

Takemata, K., Fukui, H., and Kawata, Y.: Retrieval of aerosol optical thickness over land using NOAA/AVHRR data, Adv. Space Res., 38, 2208-2211, 2006.

Tang, J. K., Xue, Y., Yu, T., and Guan, Y. N.: Aerosol optical thickness determination by exploiting the synergy of TERRA and AQUA MODIS, Remote Sens. Environ., 94, 327-334, 2005.

Von Hoyningen-Huene, W., Freitag, M., and Burrows, J. P.: Retrieval of aerosol optical thickness over land surface from top-of-atmosphere radiance, J. Geophys. Res., 108, 4260, doi:10.1029/2001JD002018, 2003.
Von Hoyningen-Huene, W., Kokhanovsky, A. A., Rozanov, V., Burrows, J. P., Hesselmans, G., Gale, L., and de Leeuw, G.: MSI aerosol retrieval algorithm for the Multi-Spectral mager (MSI) on EarthCare, ESA- Atmospheric Science Conference, Barcellona, 7-11 September 2009, available at: http://earth.eo.esa.int/workshops/atmos2009/participants/ 1283/pres_1283_vonHoyningenHuene_ppt.pdf (last access: 27 November 2012), 2009.

von Hoyningen-Huene, W., Yoon, J., Vountas, M., Istomina, L. G., Rohen, G., Dinter, T., Kokhanovsky, A. A., and Burrows, J. P.: Retrieval of spectral aerosol optical thickness over land using ocean color sensors MERIS and SeaWiFS, Atmos. Meas. Tech., 4, 151-171, doi:10.5194/amt-4-151-2011, 2011.

Xue, Y. and Cracknell, A. P.: Operational bi-angle approach to retrieve the Earth surface albedo from AVHRR data in the visible band, Int. J. Remote Sens., 16, 417-429, 1995.

Xue, Y., Guo, J. P., and Zhang, X. Y.: Aerosol Optical Thickness Retrieval over non-Lambertian Land Surface with Synergistic use of AATSR Radiance Measurements and MODIS Derived Albedo Model Parameters, Atmos. Res., 93, 736-746, 2009. 